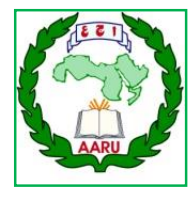

Arab Univ. J. Agric. Sci., Ain Shams Univ., Cairo, Egypt 28(1), 349-365, 2020

Website: http://ajs.journals.ekb.eq

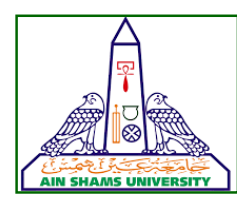

\title{
SOIL HYDROPHYSICAL PROPERTIES AS AFFECTED BY KIND OF ADDED POLYMER
}

\author{
Asmaa M. Musa ${ }^{1 *}$, Sallam ${ }^{1}$ E.E., El-Behairy ${ }^{2}$ U.A.A. and Galal ${ }^{3}$ M.E. \\ 1- Agriculture Research Center, Soil \& Water Institute \\ 2- Horticulture Dept., Fac. of Agric., Ain Shams Univ., P.O. Box 68, Hadayek Shoubra 11241, \\ Cairo, Egypt \\ 3- Soil Sci. Dept., Fac. of Agric., Ain Shams Univ., P.O. Box 68, Hadayek Shoubra 11241, Cairo, \\ Egypt \\ *Corresponding author: asmaa mosa@ hotmail.com
}

Received 24 November, 2019

Accepted 8 March, 2020

\begin{abstract}
Laboratory experiments were carried out to clarify the impact of different types of natural and synthetic polymers on some hydrophysical properties (soil hydraulic parameters) of a sandy soil. Adding $0.5 \%(\mathrm{w} / \mathrm{w})$ of each treatment to soil significantly increased water retention at saturation, field capacity, total available water and readily available water. This treatment decreased the value of inflection point on water retention curve as result of enhancing water behavior in the soil. The obtained results revealed that soil water storage significantly increased from 0.271 in control treatment (without adding polymer) up to 0.414 in treatment $\left[\mathrm{T}_{10}\right]$ (Acrylic acid + Xanthan) while, field capacity increased significantly from 0.078 in control up to 0.242 of the abovementioned treatment $\left(T_{10}\right)$. Regarding the effects of polymer application in total available water and readily available water, data revealed significant increases in the above mentioned parameters. Total available water increased from 0.044 in control treatment up to 0.153 in $T_{10}$ and readily available water increased from 0.057 in control treatment up to 0.185 in $\mathrm{T}_{10}$. Concerning values of inflection point on soil water retention curve, the obtained results revealed that, inflection point of control treatment (1000 mbar) decreased to 590 mbar, as a result of adding a mixture of polymer acrylic acid + xanthan $\left(T_{10}\right)$. Soil depletion rate decreased as due to polymer application by $25 \%$ up to $75 \%$ depending on type of polymer and wether it was added individually or in combination with another polymer. This effect led to significant differences among control treatment (control) and the other treatments. Generally, there were significant
\end{abstract}

effects of all polymers on the concerned hydrophyical properties of the studied sandy soil, i.e. storage capacity of soil water, depletion rate of soil water, soil field capacity, soil available water, readily available water and inflection point on the soil water retention curve. Acrylic acid recorded the best results concerning soil water behavior if it was added individually to the sandy soil (Treatment 2 ) or in combination with Xanthan (Treatment 10) or with Lignosulphonate (Treatment 11).

Keywords: Soil hydrophysical properties, Available water, Readily available water, Inflection point, Field capacity, Natural polymer, Synthetic polymer

\section{INTRODUCTION}

Scarcity of irrigation water is one of the major problems of agricultural production particularly in light textured soils. Sandy soils are characterized with low water retention and high drainage of irrigation water below the root zone leading to poor crop water and fertilizer use efficiencies. Therefore, development of new technologies to conserve water is becoming important to achieve a sustainable growth in agricultural production. Polymers, especially those of hydrophilic properties, known as superabsorbent polymers (SAP's) can improve water retention in soil and may increase plant growth (Zhang et al 2006). This is an important issue in arid and semi-arid regions for improving the water management of coarse-textured soils as mentioned by Abedi-Koupai et al (2008). Zhang and Wang (2006) indicated that hydrogel soil conditioners have the ability to absorb water in quite a hundred times its original weight within short 
period of time and desorbs the absorbed water under stress conditions. The hydrogel soil conditioners retain water up to 400 times their weight and release $95 \%$ of the retained water to growing plants, (Bowman and Evans, 1991). Furthermore, the hydrogels soil conditioners markedly affects soil permeability, soil density, soil structure, soil texture, and evaporation and water infiltration rate. Hydrogel soil conditioners also increase the amount of available water in the root zone, resulting in increased irrigation intervals (El-Hady et al 2009) However, there is much need to explore some different types of polymers to enhance the soil water retention capacity and water balance on root zone and consequently improve crop yield and its quality as mentioned by Dorraji et al (2010).Several investigations were conducted in the last two decades particularly in regions which suffer from scarcity in water resources to find out the effect of the application of synthetic hydrogel soil conditioners on promoting aggregate stability by gluing particles together within aggregates as well as by coating the aggregate surfaces, (Shainberg et al 1990). AbediKoupai et al (2008) found that the water storage at different tensions was improved significantly particularly in sandy soil treated with synthetic hydrogel soil conditioners. They added that the application of hydrogel soil conditioners can result in significant reduction in the required irrigation frequency particularly for coarse textured soils. It was observed that the application of hydrogel soil conditioners to sandy soils improved water availability to plants by increasing the water holding pores and reducing saturated hydraulic conductivity by decreasing the drainage pores (El-Hady and Abo-Sedera, 2006). Bhardwaj et al (2007) found that mixing hydrogel soil conditioners with sandy soils may decrease water percolation rates and increase water availability to crops.

On the other hand, some investigations reported that the application of hydrogel soil conditioners in sandy soils significantly increased the water retention capacity (Abedi-Koupai and Sohrab, 2004). Andry et al (2009) studied the effects of two hydrophilic polymers named carboxyl methyl cellulose (CMC) and isopropyl acrylamide (IPA) on water holding capacity of sandy soil, and found that this hydrophilic polymers can swell by absorbing large volumes of water and consequently improve water retention in sandy soils. Chen et al (2016) investigated the influence of some polymers soil conditioners_representing different side-chain charges, molecular weights, and degree of cross-link on water and nutrient retention in soils and indicated that the tested SAP's (Super Absorbent Polymer) possess high degree of cross-link help the soil retain water best. Liao et al (2016) concluded that the SAP's had a great effect on water retention in soil with suction pressure ranged between -100 and $-800 \mathrm{~cm}$, because these areas appeared the greatest increases in water content compared to the control.

Milani et al (2017) mentioned that, the hydrogel particles are also taken as miniature water reservoir in the soil and water will be released from these reservoirs by roots through osmotic pressure difference. When the hydrogel soil conditioners is mixed with the soil, it forms an associate amorphous gelatin-like mass on hydration and is great of absorption and desorption for an extended time, thus acts as a slow release supply of water within the soil. However, in different types of soils, the effect of hydrogel application on soil water retention and release characteristics must be fully investigated before recommending hydrogel for further commercial use in the agriculture Abobatta, (2018).

Generally, agricultural uses with polymers can change the different soil characteristics through the following different mechanisms Implement waterholding capacity of the soil, increasing soil permeability, improving water retention on different soil types, increasing the water use efficiency, increasing irrigation intervals due to increasing the time to reach a permanent wilting point, minimizing soil erosion and water run-off, implement soil penetration and infiltration, decrease soil compaction tendency and improving soil drainage Abobatta, 2018).

\section{MATERIALS AND METHODS}

Laboratory experiments were conducted to investigate the influences of adding different types of polymers on soil hydrophysical properties, i.e. hydraulic parameters and water retention properties of a sandy soil. Soil sample was collected from 0-30 $\mathrm{cm}$ soil depth, Pivot No.14 of a farm located at 85 km from Cairo along Cairo-Alex. Desert Road. Disturbed and undisturbed soil samples were collected to determine some physical and chemical properties using the standard methods described by Klute (1986) and Page (1982). Results obtained are presented in Tables (1 and 2).

This experiment included 15 polymer soil conditioner treatments with $0.5 \%(\mathrm{w} / \mathrm{w})$ as recommended application rate, besides of the control treatment (without adding any polymer) as shown in Table (3). Therefore, the air-dried soil was sub - divided into 16 parts. Each part of soil received the calculated amount of the proper polymer (polymers) treatment and then mixed thoroughly. 
Table 1. Some physical properties of the used soil sample

\begin{tabular}{|c|c|c|c|c|c|c|c|}
\hline \multicolumn{4}{|c|}{${ }^{*}$ Particle size distribution \% } & \multirow{2}{*}{ Textural class } & $\begin{array}{c}\rho_{b} \\
\mathbf{g} / \mathbf{c m}^{3}\end{array}$ & $\begin{array}{c}\rho_{\text {s }} \\
\mathbf{g} / \mathbf{c m}^{3}\end{array}$ & $f$ \% \\
\hline Coarse Sand & Fine Sand & Silt & Clay & & & \\
\hline 16.2 & 54.2 & 20.2 & 9.4 & loamy sand & 1.65 & 2.58 & 36.04 \\
\hline
\end{tabular}

* According to scheme of ISSS (International soil science society)

$\rho_{\mathrm{b}} \ldots$ Soil bulk density $\quad \rho_{\mathrm{s}} \ldots$ Soil particle density $\quad \boldsymbol{f}$... Soil porosity

Table 2. Some chemical properties of the used soil sample

\begin{tabular}{|c|c|c|c|c|c|c|c|c|c|c|c|}
\hline \multirow{2}{*}{$\begin{array}{l}\mathrm{EC}_{\mathrm{e}} \\
\mathrm{dS} / \mathrm{m}\end{array}$} & \multirow[t]{2}{*}{$\mathrm{pH}$} & \multirow[t]{2}{*}{$\mathrm{CaCO}_{3} \%$} & \multirow[t]{2}{*}{ OM \% } & \multicolumn{4}{|c|}{$\begin{array}{l}\text { Water soluble cations } \\
\text { meq/l }\end{array}$} & \multicolumn{4}{|c|}{$\begin{array}{l}\text { Water soluble anions } \\
\text { meq/l }\end{array}$} \\
\hline & & & & $\mathrm{K}^{+}$ & $\mathrm{Na}^{+}$ & $\mathrm{Mg}^{++}$ & $\mathrm{Ca}^{++}$ & $\mathrm{Cl}^{-}$ & $\mathrm{SO}_{4}^{-}$ & $\mathrm{HCO}_{3}{ }^{-}$ & $\mathrm{CO}_{3}=$ \\
\hline 1.86 & 7.67 & 9.56 & 1.38 & 0.10 & 9.55 & 4.23 & 4.72 & 10.9 & 4.11 & 3.59 & nd \\
\hline
\end{tabular}

nd .... Non detected

Table 3. Characterization of used treatments

\begin{tabular}{|c|c|c|c|}
\hline Treatment & Used polymer & Polymer type & Polymer classification \\
\hline Control & Without any polymer & -- & -- \\
Treatment 1 & Acrylamide ( bis) & Synthetic & Hydrophilic linear polymers \\
Treatment 2 & Acrylic acid & Synthetic & Hydrophilic linear polymers \\
Treatment 3 & Xanthan & Natural & Hydrophilic linear polymers \\
Treatment 4 & Lignosulphonate & Natural & Hydrophilic linear polymers \\
Treatment 5 & 1,3,6Beta glucan & Natural & Hydrophilic linear polymers \\
Treatment 6 & Acrylamide + Acrylic acid & & \\
Treatment 7 & Acrylamide +xanthan & & \\
Treatment 8 & Acrylamide +Lignosulphonate & & \\
Treatment 9 & Acrylamide $+1,3,6$ Beta glucan & & \\
Treatment 10 & Acrylic acid + Xanthan & & \\
Treatment 11 & Acrylic acid + Lignosulphonate & & \\
Treatment 12 & Acrylic acid $+1,3,6$ Beta glucan & & \\
Treatment 13 & Xanthan + Lignosulphonate & & \\
Treatment 14 & Xanthan+1,3,6 Beta glucan & & \\
Treatment 15 & Lignosulphonate +1,3,6 Beta glucan & & \\
\hline
\end{tabular}

The treated soil samples and control one were packed in plastic cups of $5 \mathrm{~cm}$ height and $10 \mathrm{~cm}$ upper diameter, $8 \mathrm{~cm}$ lower diameter (pored base) up to compose a bulk density $=1.65 \mathrm{~g} / \mathrm{cm}^{3}$ with 4 replicates.
Soil cups were saturated with tap water, leaved to drain the excess water through the pored base. After equilibrium, no drain water from plastic cups, each cup was covered with a lid and its weight was recorded after 1, 6, 12, 24, 48, 72 and 96 hours to obtain soil depletion data, Table (4) and Fig. (1). 

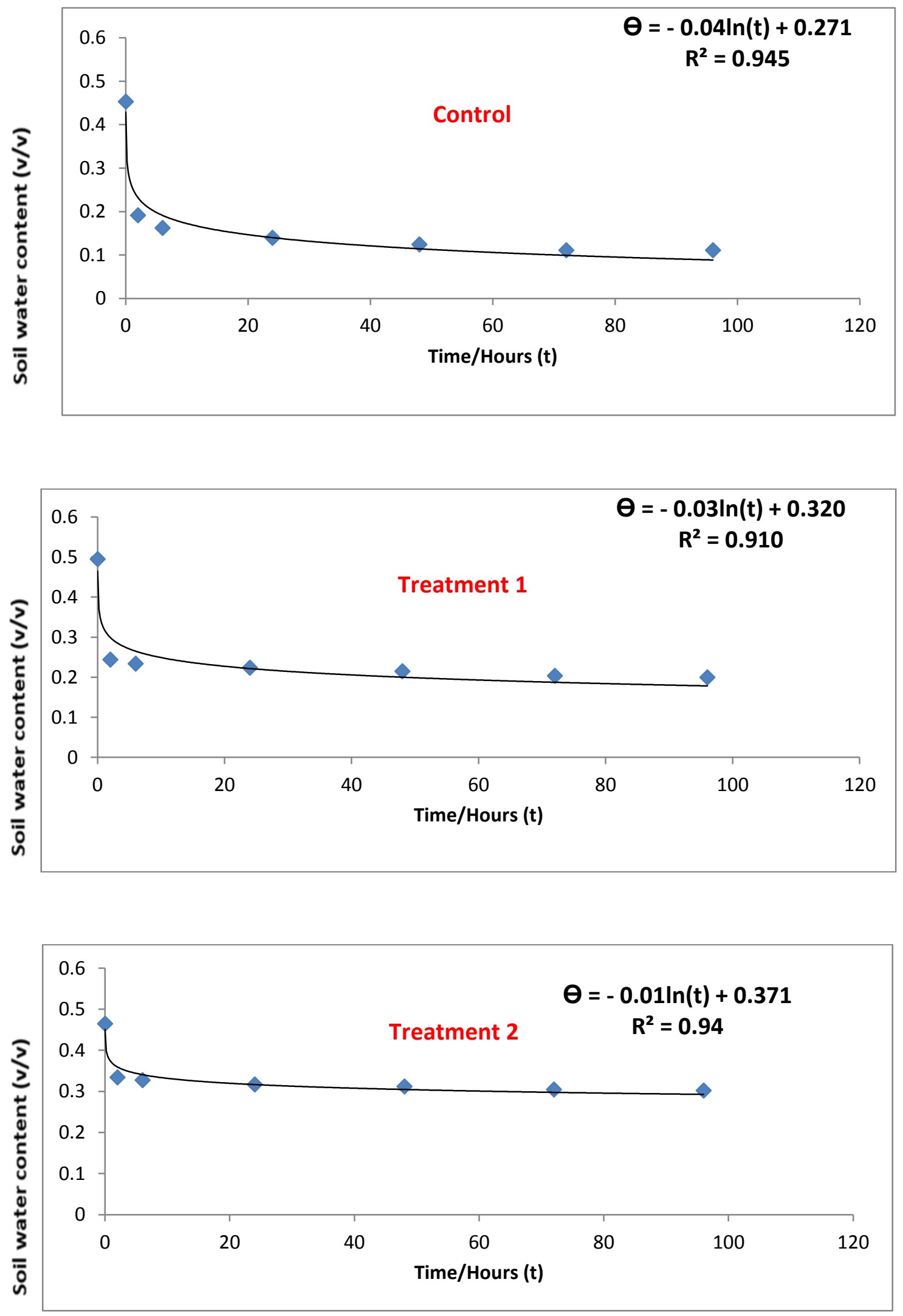

AUJASCI, Arab Univ. J. Agric. Sci., 28(1), 2020 

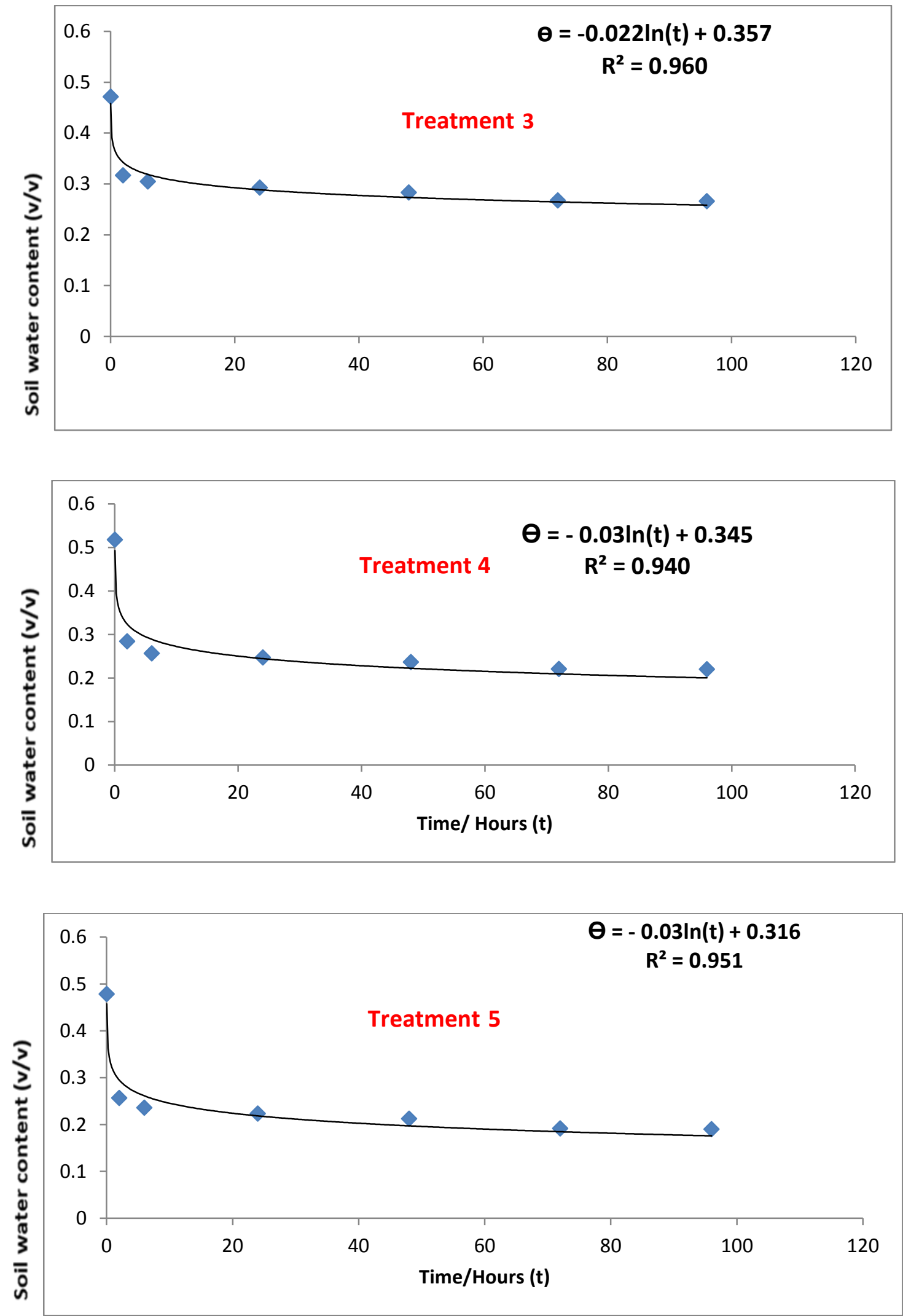

AUJASCI, Arab Univ. J. Agric. Sci., 28(1), 2020 

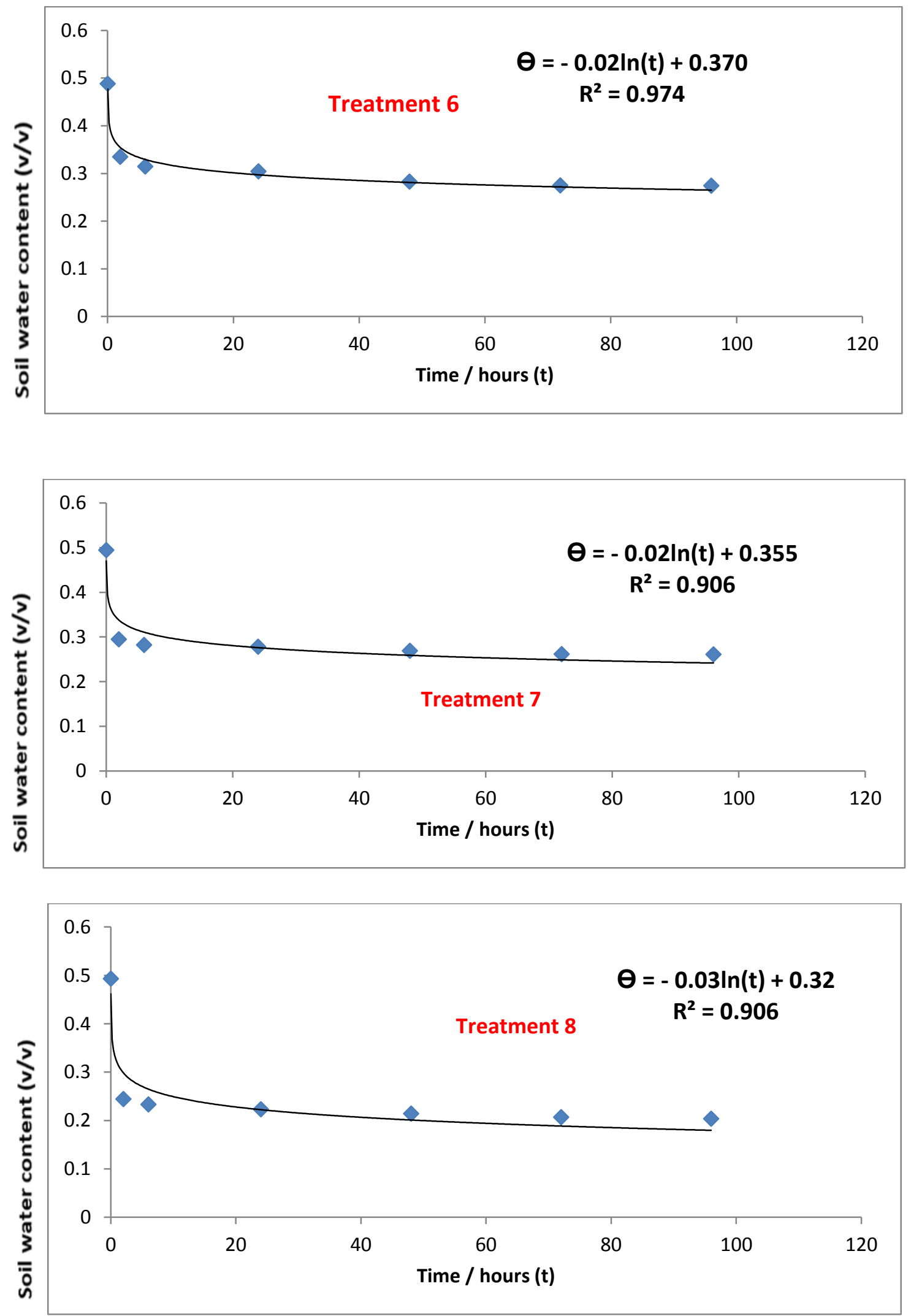

AUJASCI, Arab Univ. J. Agric. Sci., 28(1), 2020 

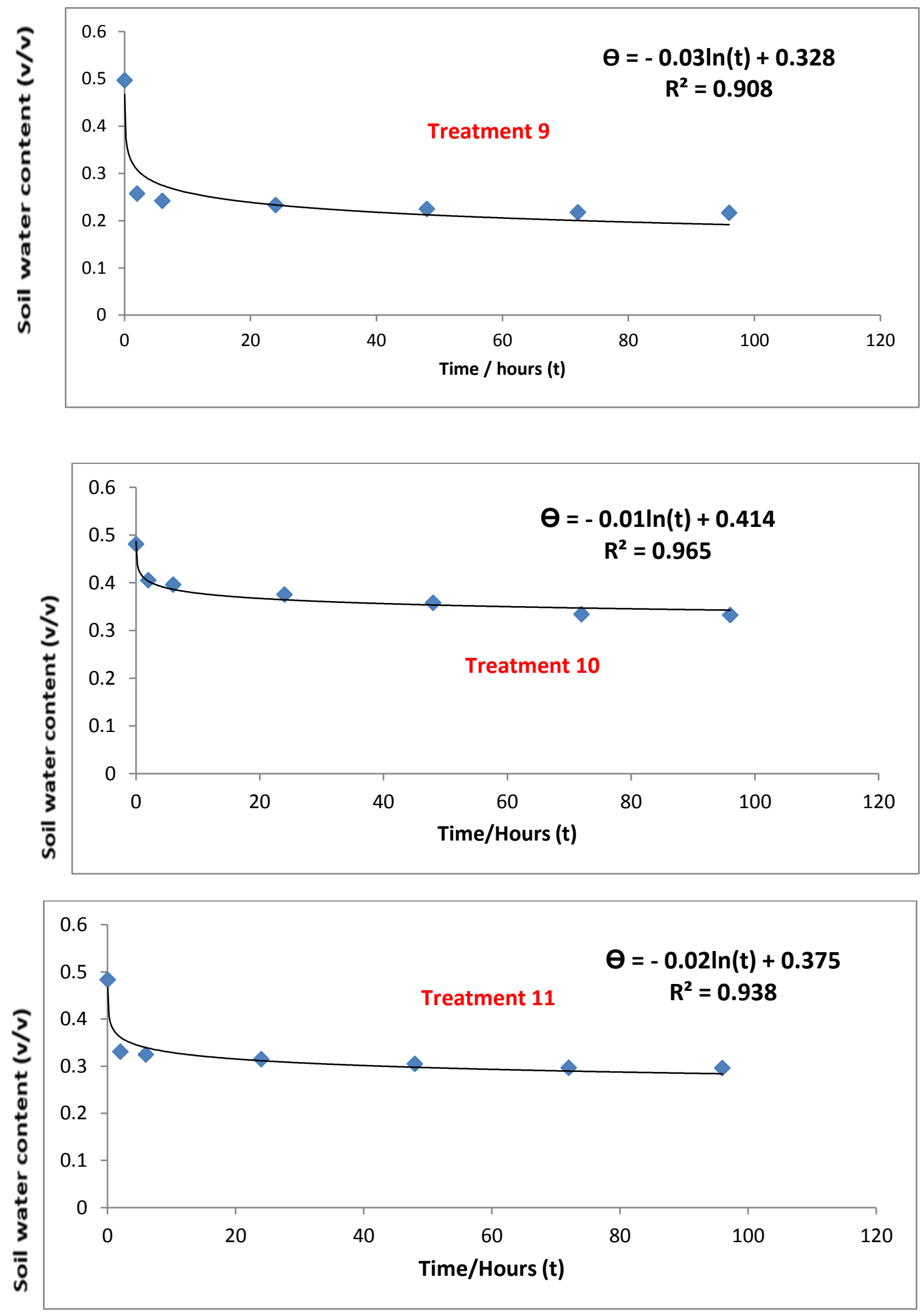

AUJASCI, Arab Univ. J. Agric. Sci., 28(1), 2020 

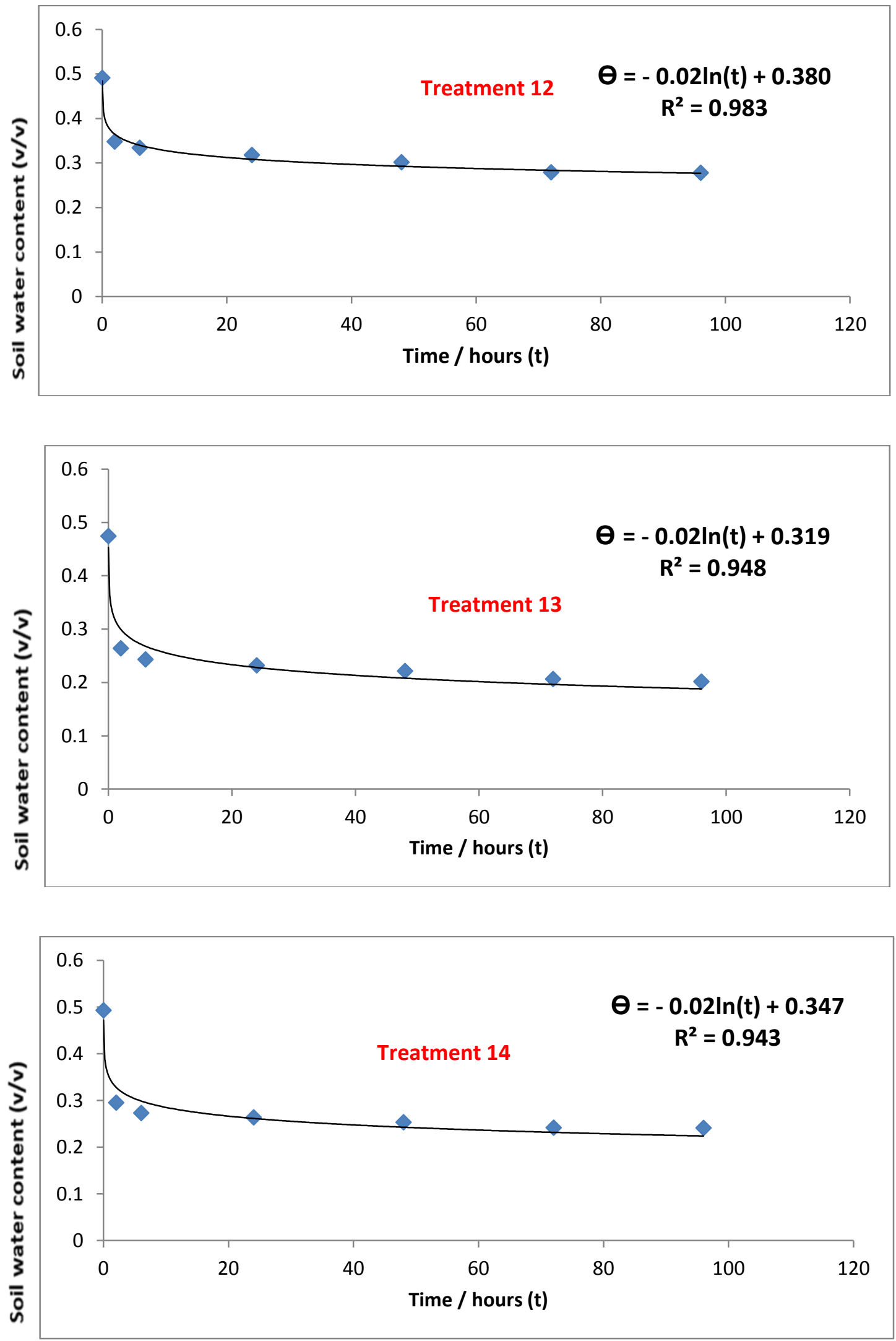

AUJASCI, Arab Univ. J. Agric. Sci., 28(1), 2020 


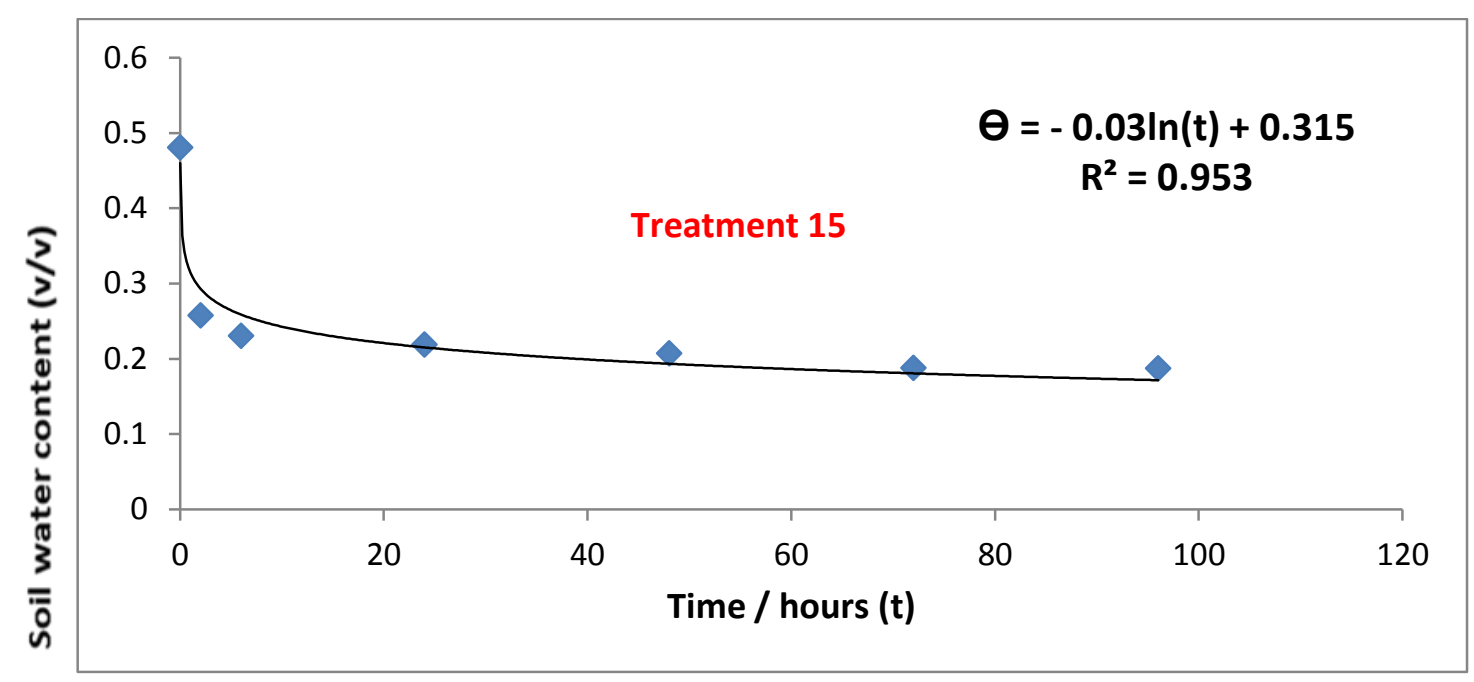

Fig. 1. Soil water depletion curve as affected by the investigated treatments

Table 4. Depletion rate and storage capacity of soil water as affected by the investigated treatments

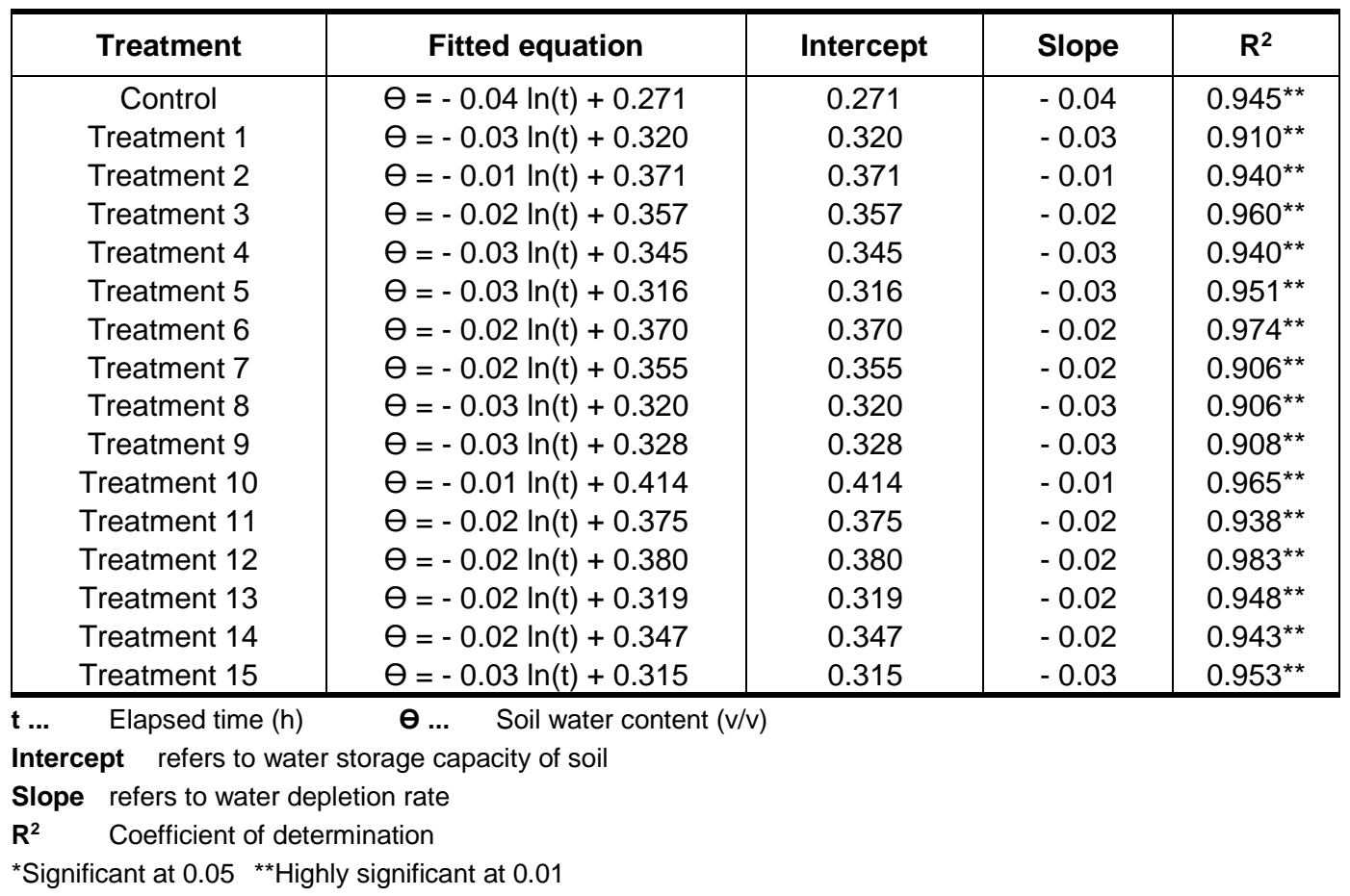

Soil water retention curve are determined using treated soil sample and control one as described by Klute (1986), then data were presented in Table (5) and illustrated in Fig. (2).

Inflection point of soil water retention curve was calculated from soil water retention data that occur where the second derivative of fitted equation is zero Bronshtein, (2004).
The obtained data were subjected to the analysis of variance (ANOVA). The $F$-test and $T$-test were used to identify the significance of differences among the control on one side and each other treatment on the other one, (Steel and Torrie, 1980). The data were also subjected to simple linear and non-linear regression analyses. The coefficients of determination $\left(R^{2}\right)$ were verified. 

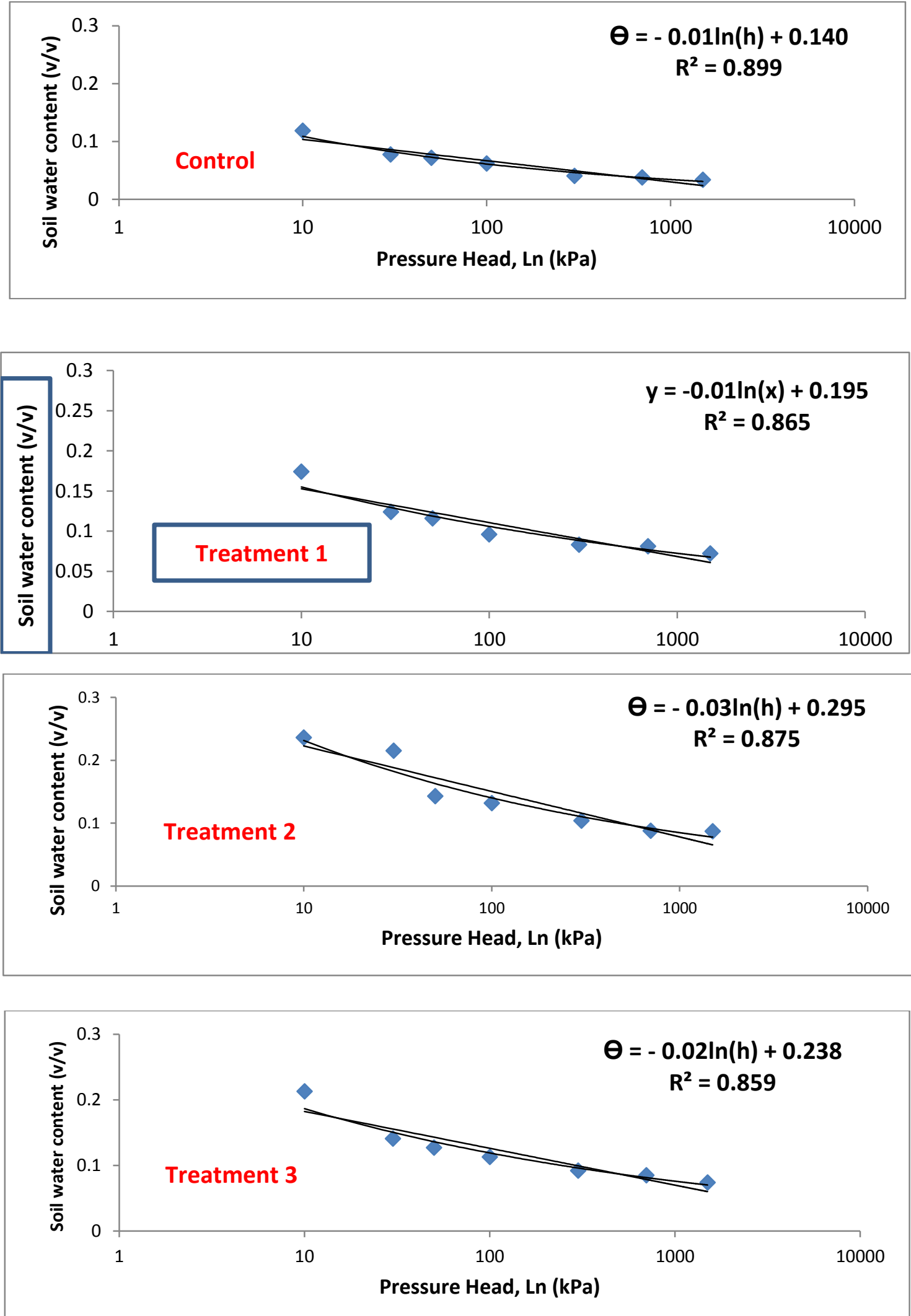

AUJASCI, Arab Univ. J. Agric. Sci., 28(1), 2020 

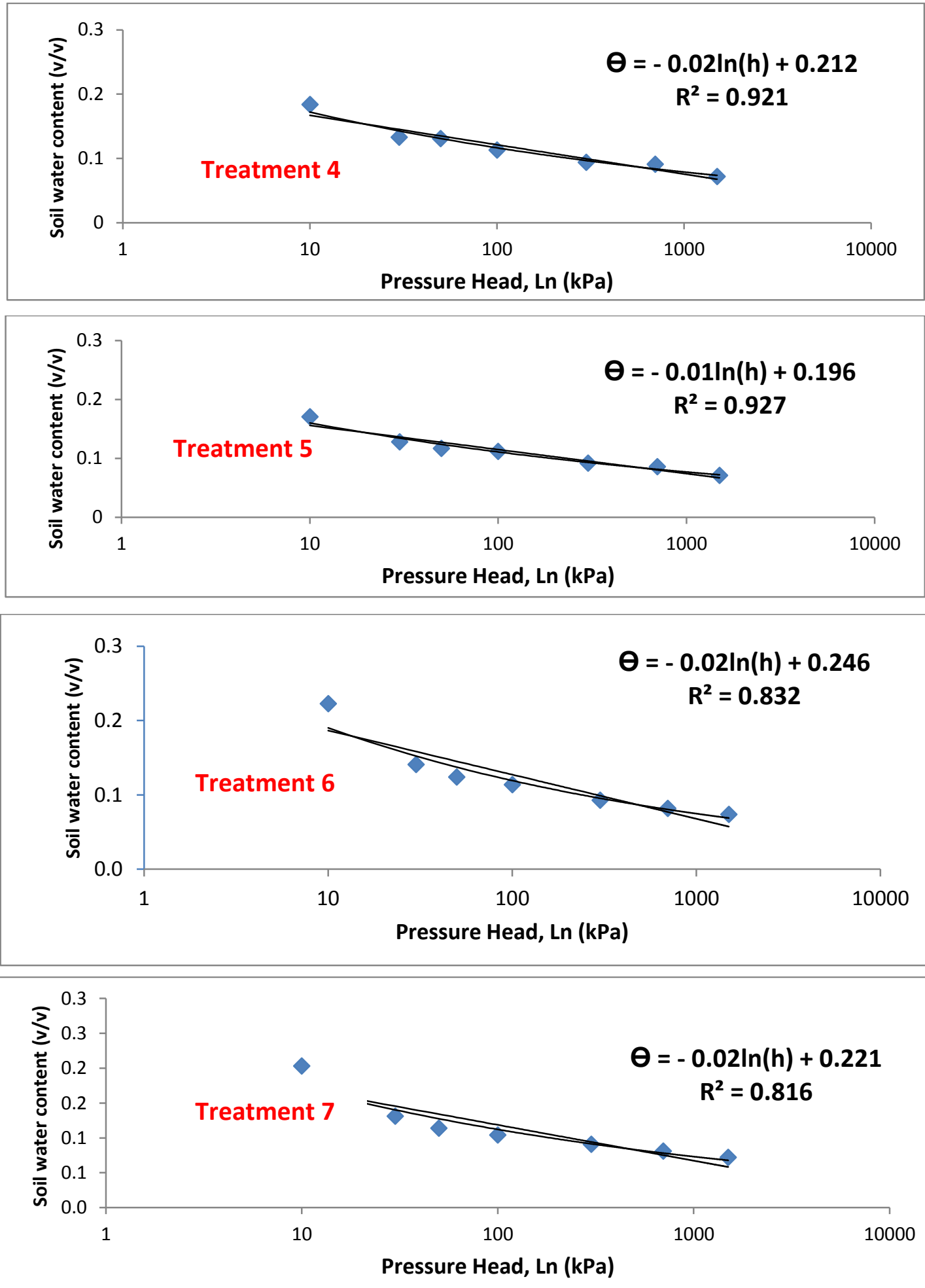

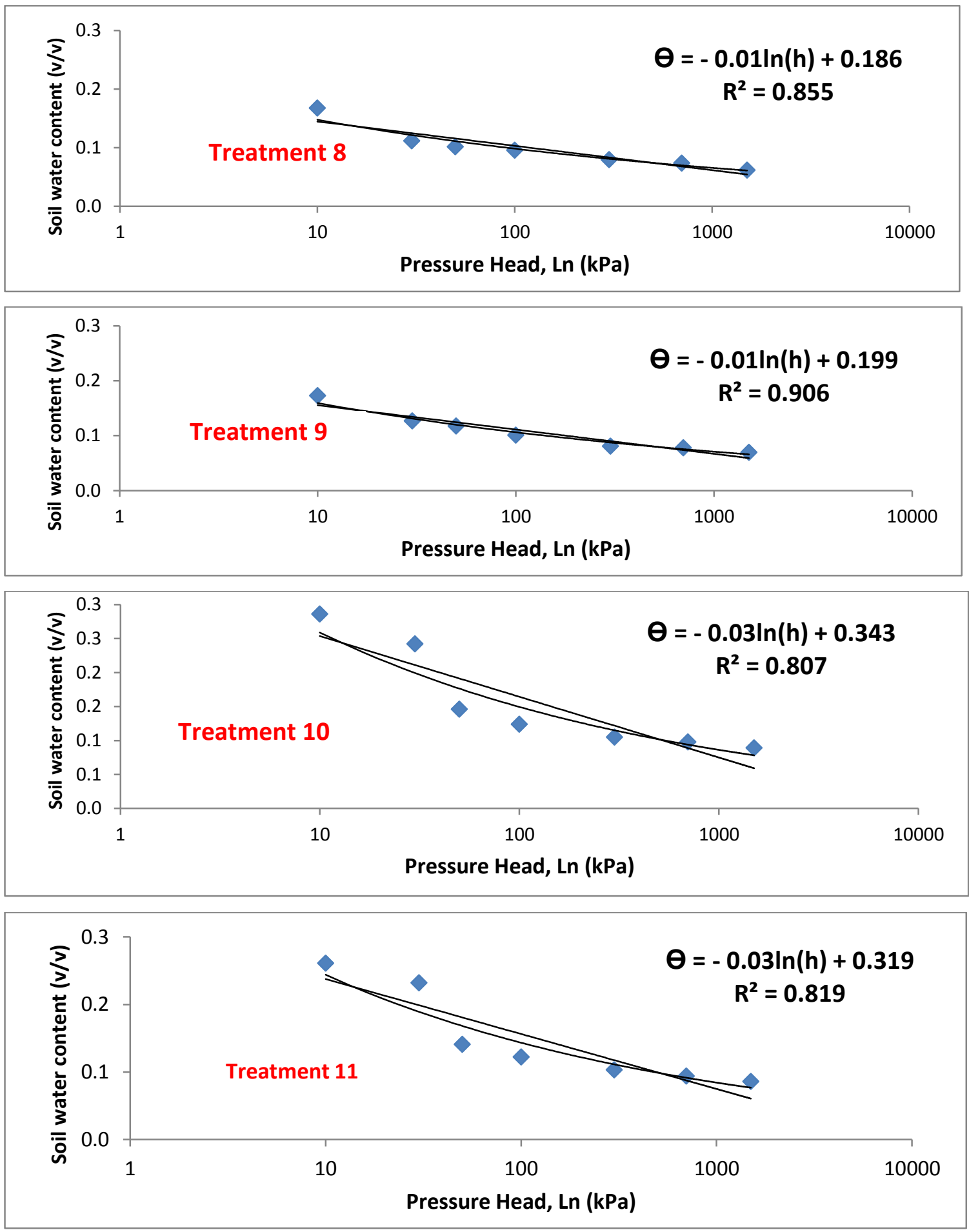

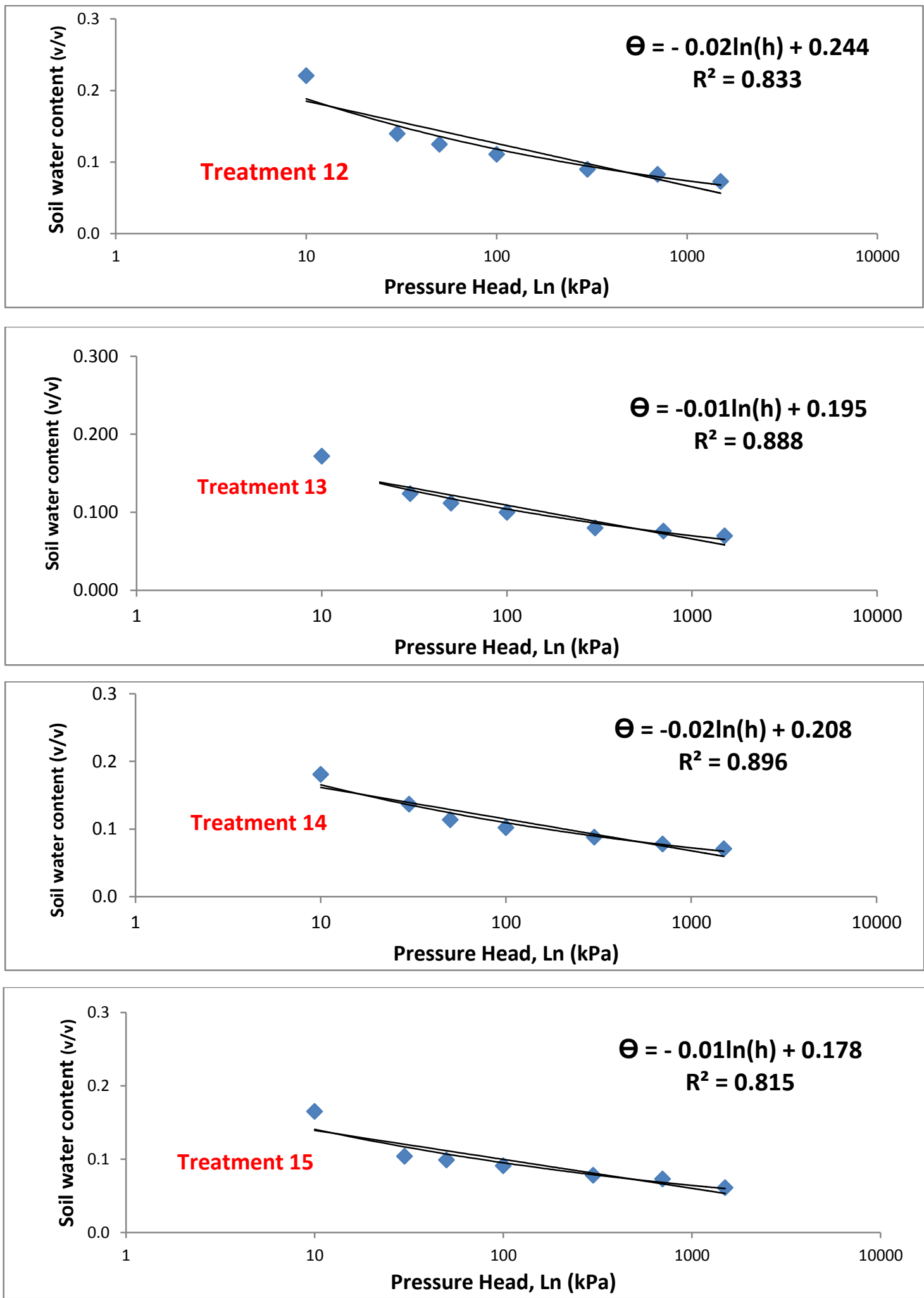

Fig 2. Soil water retention curve as affected by the investigated treatments and their fitted equations 
Table 5. Soil water retention equations as affected by the investigated treatments

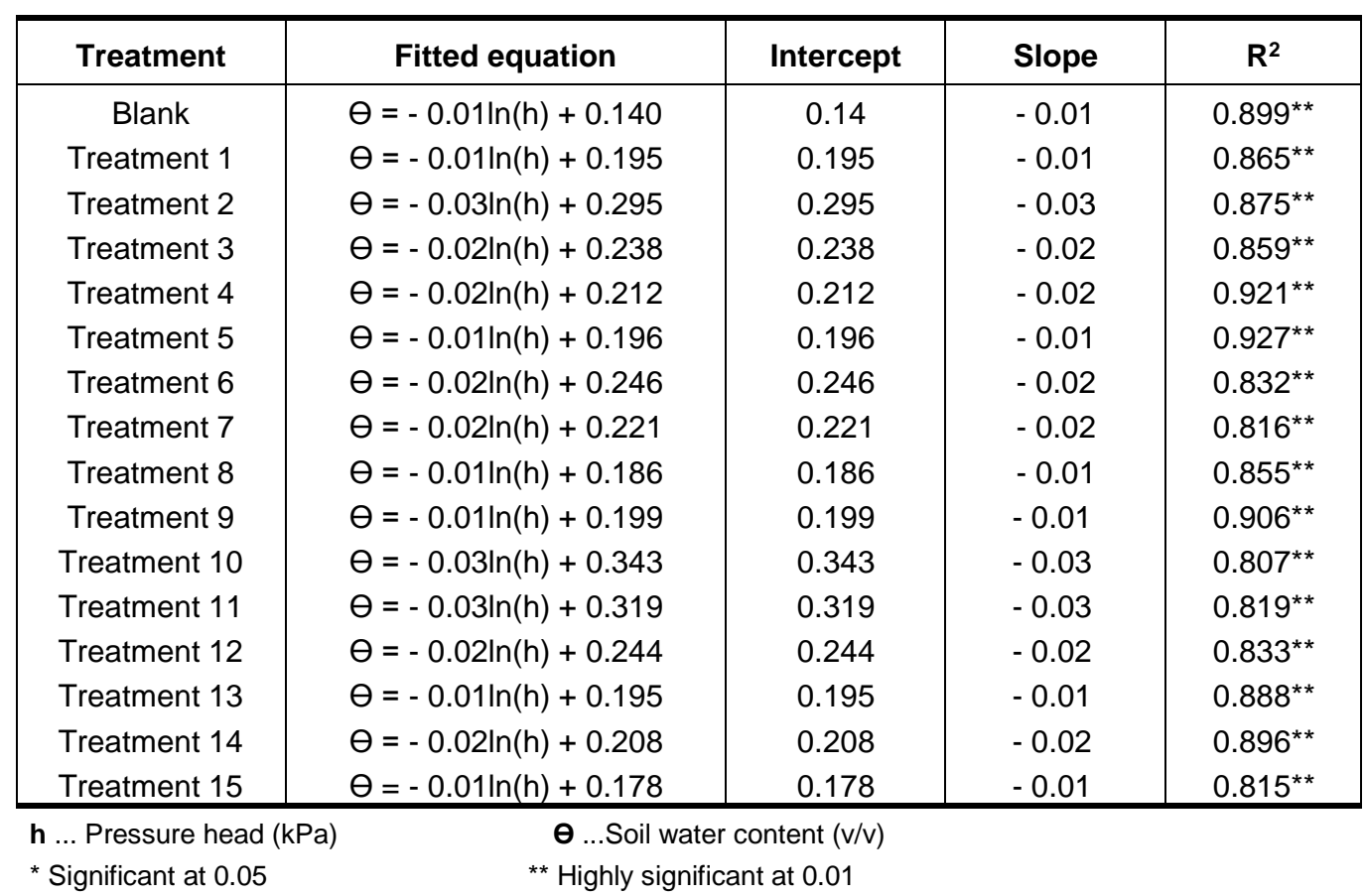

Table 6. Inflection point at soil water retention curve, field capacity and available water $(\mathrm{v} / \mathrm{v})$ of the studied soil sample as affected by the investigated treatments

\begin{tabular}{|c|c|c|c|c|}
\hline Treatment & $\begin{array}{l}\text { Inflection point } \\
\text { (mbar) }\end{array}$ & $\begin{array}{c}\text { Field capacity } \\
(v / v)\end{array}$ & $\begin{array}{c}\text { Available water } \\
(\mathbf{v} / \mathbf{v})\end{array}$ & $\begin{array}{c}\text { Readily Available water } \\
(\mathrm{v} / \mathrm{v})\end{array}$ \\
\hline Control & 1000 & 0.078 & 0.044 & 0.057 \\
\hline Treatment 1 & $775^{\star}$ & $0.124^{*}$ & 0.052 & $0.078^{*}$ \\
\hline Treatment 2 & $665^{*}$ & $0.215^{\star \star}$ & $0.128^{\star \star}$ & $0.104^{\star *}$ \\
\hline Treatment 3 & $750^{*}$ & $0.141^{*}$ & $0.067^{*}$ & $0.100^{\star *}$ \\
\hline Treatment 4 & $750^{*}$ & $0.133^{*}$ & $0.061^{*}$ & $0.071^{*}$ \\
\hline Treatment 5 & $900^{*}$ & $0.128^{*}$ & $0.057^{*}$ & $0.059^{*}$ \\
\hline Treatment 6 & $750^{*}$ & $0.141^{*}$ & $0.067^{*}$ & $0.109^{\star *}$ \\
\hline Treatment 7 & $888^{*}$ & $0.131^{*}$ & $0.059^{*}$ & $0.099^{* *}$ \\
\hline Treatment 8 & $666^{*}$ & $0.112^{*}$ & 0.05 & $0.072^{*}$ \\
\hline Treatment 9 & $777^{*}$ & $0.127^{\star}$ & $0.057^{*}$ & $0.077^{*}$ \\
\hline Treatment 10 & $590^{\star *}$ & $0.242^{\star \star}$ & $0.153^{\star *}$ & $0.185^{\star \star}$ \\
\hline Treatment 11 & $595^{\star *}$ & $0.232^{\star *}$ & $0.146^{\star *}$ & $0.150^{* *}$ \\
\hline Treatment 12 & $830^{*}$ & $0.14^{*}$ & $0.067^{*}$ & $0.110^{* *}$ \\
\hline Treatment 13 & $777^{\star}$ & $0.124^{*}$ & $0.054^{*}$ & $0.072^{*}$ \\
\hline Treatment 14 & $777^{\star}$ & $0.137^{*}$ & $0.066^{*}$ & $0.079^{*}$ \\
\hline Treatment 15 & $666^{*}$ & $0.104^{*}$ & $0.063^{*}$ & $0.074^{*}$ \\
\hline
\end{tabular}

Field capacity $=\theta_{330} \ldots$ Soil water content $(\mathrm{v} / \mathrm{v})$ at $P(\mathrm{mbar})$

Available water $=\theta_{330}-\theta_{15000} \ldots$. Soil water content $(\mathrm{v} / \mathrm{v})$ at $P(\mathrm{mbar})$

Readily available water $=\theta_{100}-\theta_{1000} \quad \ldots$. Soil water content $(\mathrm{v} / \mathrm{v})$ at $\mathrm{P}(\mathrm{mbar})$

* Significant deference at $0.05 \quad{ }^{* *}$ High significant deference at 0.01 


\section{RESULTS AND DISCUSSION}

Concerning the effect of adding polymers to the used sandy soil, on soil water storage capacity, Table (4) shows this relation with different polymers. The intercepts of the fitted equations that, represent water storage capacity are arranged in the following descending order: $T_{10}>T_{12}>T_{11}>T_{2}>$ $T_{6}>T_{3}>T_{7}>T_{14}>T_{4}>T_{9}>T_{8}>T_{1}>T_{5}>T_{15}$

This finding reveals that the treatments $T_{10}, T_{11}$, $\mathrm{T}_{12}$, are of the most significant effects on water storage capacity. However, the acrylic acid (Treatment 2) was the polymer of the highest significant effect on retaining water in the soil under atmospheric pressure with high significant. This finding is in harmony with that of Andy et al (2009) who found that, using hydrophilic polymers can retain large volume of water exceeds water holding capacity and consequently improve water retention in sandy soils. Data in Table (4) reveal also that, water depletion rate which represent with the slope of fitted equation confirmed the aforementioned finding.

Water depletion rate was -0.04 for the control treatment (without adding any polymer) followed by $T_{1}, T_{4}, T_{5}, T_{8}, T_{9}$ and $T_{15}$ whose corresponding value was -0.03 then $T_{3}, T_{6}, T_{7}, T_{11}, T_{12}, T_{13}$ and $T_{14}$ with $a$ value of -0.02 .

Finally, $T_{2}$ and $T_{10}$ showed the lowest value of water depletion rate, which was $0.01, \mathrm{~T}_{2}$ (Acrylic acid) was the most effective polymer retaining water in sandy soil.

Inflection point on soil water retention curve divided this curve into two parts; each one of them differs from the other concerning water behavior. Readily available water is found between 10-100 $\mathrm{kPa}$ (100-1000 mbar), which represents the available range of soil water. So, if the value of inflection point is more than or equal $100 \mathrm{kPa}$ it means low amount of available water, (Narjary 2012).

Soil water changes in the $(0-10 \mathrm{kPa})$ range (unavailable to plants) occurred due to the soil sample which was not treated with a polymer, (Narjary et al 2012).

Water release per unit suction change in the 10$100 \mathrm{kPa}$ range (available to plants) in soil sample not treated with polymer were significantly lower compared to that in soil samples treated with polymers.

Data in Table (6) revealed that the highest value of suction at the inflection point was found in the control treatment (not treated soil sample). This value i.e., $1000 \mathrm{mbar}(100 \mathrm{kPa})$ represents the lower limit of readily available water while, $\mathrm{T}_{10}$ and
$T_{11}$ recorded the lowest values of suction at inflection point 590, 595 mbar, respectively. Consequently, this means that, $T_{10}$ and $T_{11}$ have the most effective action in retaining water in availability range (10-100 kPa). Concerning the effect of each polymer, Table (5) reveals that, the acrylic acid was the most effective polymer whether it was added individually or combined with others.

Data of Table (6) reveal that, field capacity increased from $0.078(\mathrm{v} / \mathrm{v})$ (Control) to $0.215,0.242$ and $0.232(\mathrm{v} / \mathrm{v})$ for $\mathrm{T}_{2}, \mathrm{~T}_{10}$ and $\mathrm{T}_{11}$. Respectively, while available water increased from $0.044(\mathrm{v} / \mathrm{v})$ (Control) to $0.128,0.153$ and $0.146(\mathrm{v} / \mathrm{v})$ for $\mathrm{T}_{2}, \mathrm{~T}_{10}$ and $T_{11}$, respectively.

Also, readily available water, increased from $0.057(\mathrm{v} / \mathrm{v})$ to $0.104,0.185$ and $0.150(\mathrm{v} / \mathrm{v})$ for $\mathrm{T}_{2}, \mathrm{~T}_{10}$ and $T_{11}$, respectively and the difference among these increments were highly significant.

These findings are in agreement with those of Zhang et al (2006), Andry et al (2009), Dorraji et al (2010), Narjary et al (2012) and Nada \& Blumenstein (2015).

\section{REFERENCES}

Abedi-Koupai J. and Sohrab F. 2004. Evaluating the application of superabsorbent polymers on soil water capacity and potential on three soil textures. Iran J. of Polymer Sci. and Technology 17, 163-173.

Abedi-Koupai J., Sohrab F. and Swarbrick G. 2008. Evaluation of hydrogel application on soil water retention characteristics. J. of Plant Nutrition 31, 317-331.

Abobatta W. 2018. Impact of hydrogel polymer in agricultural sector. Adv. Agr. Environ Sci., 1(2), 59-64.

Andry H., Yamamoto T., Irie T., Moritani S., Inoue M. and Fujiyama H. 2009. Water retention, hydraulic conductivity of hydrophilic polymers in sandy soil as affected by temperature and water quality. J. of Hydrology, 373(1-2), 177-183.

Banedjschafie S. and Durner W. 2015. Water retention properties of a sandy soil with superabsorbent polymers as affected by aging and water quality. J. of Plant Nutrition and Soil Sci., 178(5), 798-806.

Bhardwaj A.K., Shainberg I., Goldstein D., Warrington D.N. and Levy G.J. 2007. Water retention and hydraulic conductivity of cross-linked polyacrylamides in sandy soils. Soil Sci. Society of America J., 71(2), 406-412. 
Chen F.M., Wondergem J. and Peterson M. 2016. The Effect of Polymers for Soil Stabilization and Soil Nutrient Retention. Int. J. Appl. Sci. Res. Rev., 3, 1-6.

Dorraji S.S., Golchin A. and Ahmadi S. 2010. The effects of hydrophilic polymer and soil salinity on corn growth in sandy and loamy soils. CleanSoil, Air, Water, 38(7), 584-591.

Ekebafe L.O., Ogbeifun D.E. and Okieimen F.E. 2011. Polymer applications in agriculture. Biokemistri, 23(2), 81-89.

El-Hady O.A. and Abo-Sedera S.A. 2006. Conditioning effect of composts and acrylamide hydrogels on a sandy calcareous soill, Physico-biochemical properties of the soil. Int. J. of Agric. Biology, 8, 876-884.

El-Hady O.A., El-Kader A.A. and Shafi A.M. 2009. Physico-bio-chemical properties of sandy soil conditioned with acrylamide hydrogels after cucumber plantation. Australian J. of Basic and Applied Sci. 3(4), 3145-3151.

Klute A. 1986. Methods of Soil Analysis, Part 1, Second edition. Physical and Mineralogical properties. Agronomy, Monograph, No. 9, Madison Wisconson, USA, pp. 425-441.

Liao R., Wu W., Ren S. and Yang P. 2016. Effects of superabsorbent polymers on the hydraulic parameters and water retention properties of soil. J. of Nanomaterials, 37, 1-11.

Milani P., França D. and Balieiro A.G. 2017. Polymers and its applications in Agric. Polímeros. 27(3), 256-266.
Narjary B., Aggarwal P., Singh A., Chakraborty D. and Singh R. 2012. Water availability in different soils in relation to hydrogel application. Geoderma, 187, 94-101.

Page A.L. 1982. Methods of soil analysis part 2. Chemical and Microbiological properties. Second Edition, Agronomy, Monograph, No. 9, Madison, Wisconson, USA, pp. 199-223.

Paluszek J. and Zembrowski W. 2008. Improvement of water-air properties of eroded soils in a loess landscape after the application of agro hydrogel. Ann. Warsaw Univ. of Life Sci. SGGW. Land Reclamation 39, 85-93.

Semendyayev B. 2004. Handbook of Mathematics ( $4^{\text {th }}$ ed.). Berlin: Springer. 231 p. ISBN3-54043491-7.

Shainberg I., Warrington D. and Rengasarny P. 1990. Water quality and PAM interactions in reducing surface sealing. Soil Sci., 149, 301-307.

Steel R.G.D. and Torrie T.H. 1980. Principles and procedures of statistics. $2^{\text {nd }}$ ed. McGraw Hill Book Co. Inc., New York, USA, 275 p.

Zhang J., Li A. and Wang A. 2006. Study on Superabsorbent composite. VI. Preparation, characterization and swelling behaviors of starch phosphate-graft-acrylamide/attapulgite Superabsorbent composite. Carbohydrate Polymers, 65(2), 150-158.

Zhang J., Chen H., Li P. and Wang A. 2006. Study on superabsorbent composite, 14. Preparation of poly (acrylic acid) / organo-attapulgite composite hydrogels and swelling behaviors in aqueous electrolyte solution. Macromol. Mater. Eng., 291, 1529-1538. 
مجلة اتحاد الجامعات العربية للعلوم الزراعية، جامعة عين شمس، القاهرة، مصر مجلد(28)، عدد(1)، 365-349، 2020

Website: http://ajs.journals.ekb.eg

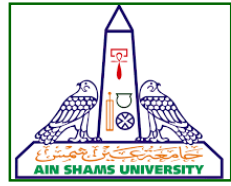

365

الصفات الهيدروفيزيقية للأراضى الرملية وتأثرها بنوع البوليمر المضاف

[26]

$$
\begin{aligned}
& \text { أسماء محمد موسى1" - عصام الدين سلام } 1 \text { - أسامده أحمد على البحيري2 - }
\end{aligned}
$$

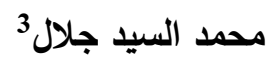

$$
\begin{aligned}
& \text { 1- مركز البحوث الزراعية - معهد الأراضي والمياه - الجيزه - مصر } \\
& \text { 2- قسم البساتين - كلية الزراعة - جامعة عين شمس - ص.ب } 68 \text { - حدائق شبرا } 11241 \text { - القاهرة - مصر } \\
& \text { 3- قسم علوم الأراضي - كلية الزراعة - جامعة عين شمس - ص.ب } 68 \text { - حدائق شبرا } 11241 \text { - القاهرة - مصر }
\end{aligned}
$$

*Corresponding author: asmaa mosa@hotmail.com

أيضاً. بخصوص قيمة الثد الرطوبى عند نقطة الانقلاب النقاء

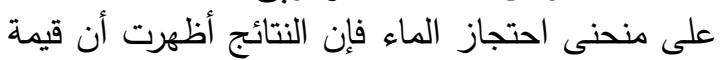

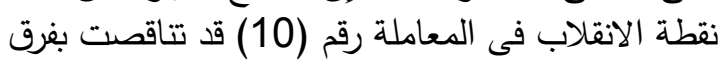
معنوى جداً من 1000 ملليبار فى معاملة (الكنترول)

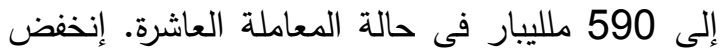

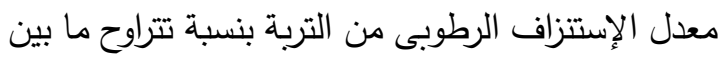

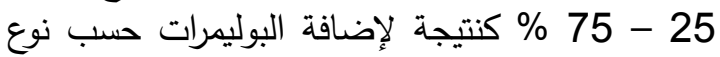

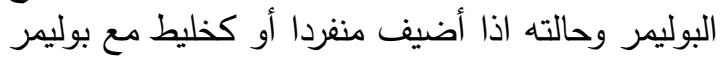

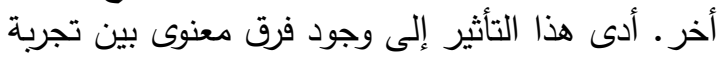
الكنترول والمعاملات المختلفة والتئ

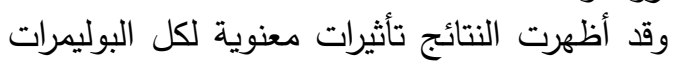

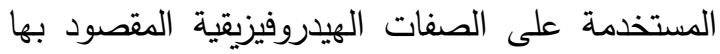
البحث مثل سعة حفظ الماء بالتربة ومعدل الإستنزاف

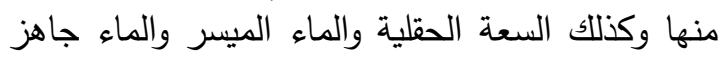
التيسر ونقطة الإنقلاب على منحنى إحتجاز الماء التهاء

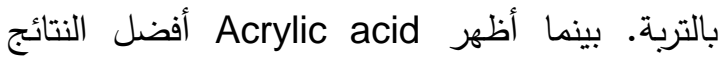

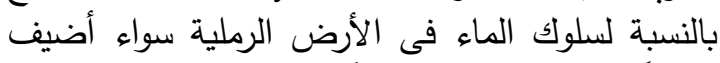

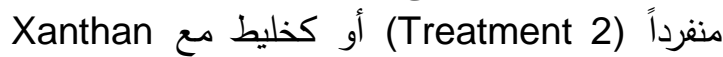
(Treatment 11) Lignosulphonate.

مع (Treatment 10).

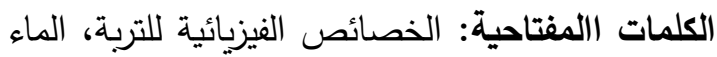

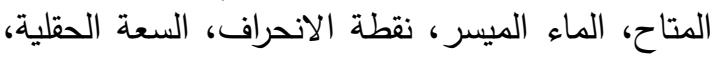

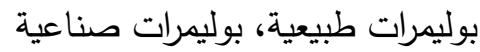<smiles>[AlH2][AlH2]</smiles>

أجريت عدة تجارب معملية لتوضيح تأثير أنواع طبيعية وصناعية من البوليمرات على بعض التص الخواص الهيدروفيزيقية (المعايير الهيدروليكية ) للأرض العضية الرملية.

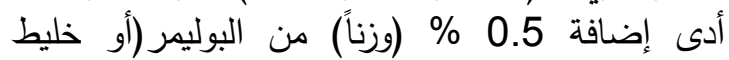

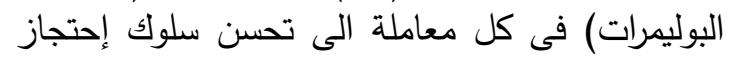

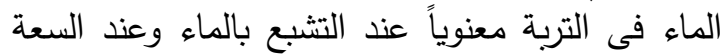

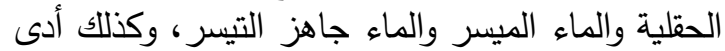

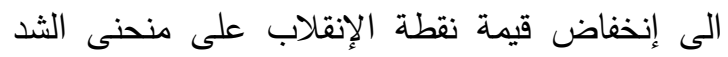
الرطوبى كنتيجة لتحسن سلوك الماء في التربة التربة. أوضحت النتائج المتحصل عليها أن السعة التشبعية التربة العظمى للتربة قد ازدادت زيادة معنوية من 0.271

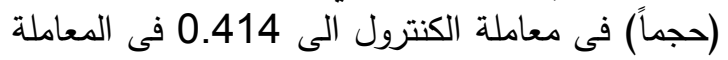

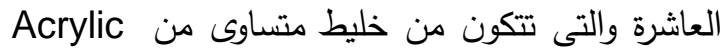
acid+ Xanthan زيادة معنوية من 0.078 (حجما) فى معاملة الكنترول

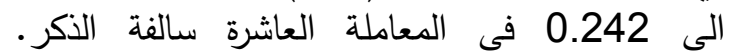
وبخصوص تأثير إضافة البوليمر على كل من الماء

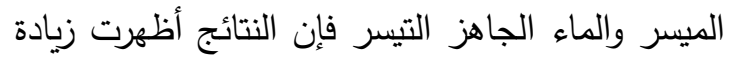

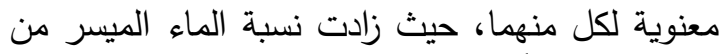
0.044 حجماً (فى معاملة الكنترول) الى 0.153 (10)

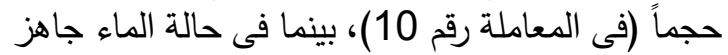

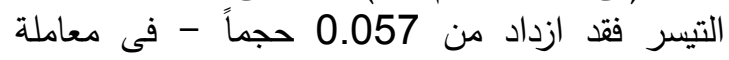
الكنترول - الى 0.185 حجما فى المعاملة العاشرة 